\title{
Pengembangan Implementasi SOP (Standart Operational Procedure) Budidaya Salak Pondoh (Salacca edulis) Organik Studi Kasus Kelompok Tani Kusuma Mulya Kelurahan Girikerto Kapanewon Turi Kabupaten Sleman Daerah Istimewa Yogyakarta (DIY)
}

\author{
Akhyar Rafi'i' ${ }^{*}$, Asih Farmia ${ }^{1}$, Galuh HE Akoso' \\ ${ }^{1}$ Program Studi Penyuluhan Pertanian Berkelanjutan, Jurusan Pertanian, Politeknik Pembangunan \\ Pertanian Yogyakarta-Magelang \\ *Corresponding author: muhammad.akhyarrafii@gmail.com
}

\begin{abstract}
Abstrak
Kajian ini bertujuan untuk mengetahui komponen aspek internal, eksternal dan pengembangan taraf implementasi SOP dalam budidaya salak pondoh organik di Kelompok Tani Kusuma Mulya Kalurahan Girikerto. Kajian ini dilaksanakan pada bulan Maret hingga Juni 2021 di Kelompok Tani Kusuma Mulya kelurahan Giriketo Kapanewon Turi kabupaten Sleman. Penentuan objek penelitian Mulai dari Kabupaten hingga desa dipilih secara purposive, sedangkan untuk responden ditentukan menggunakan sampel jenuh. Terdapat 20 responden dalam kajian ini dimana 15 orang sebagai responden utama dan 5 orang sebagai responden pendukung. Teknik pengumpulan data menggunakan Indeepth interview, kuesioner dan focus group discussion. Teknik analisis data menggunakan analisis Desktiptif dan Skala Likert Modifikasi karena penelitian berupa penelitian gabungan (mix methode). Berdasarkan hasil kajian komponen aspek internal dalam kajian ini meliputi sumberdaya, komunikasi dan disposisi. Untuk variabel sumberdaya mendapatkan skor 825 dengan persentase $65,5 \%$ dan masuk dalam kategori sedang. Variabel komunikasi mendapatkan skor 196 dengan persentase 81,7\% masuk dalam kategori tinggi. Variabel disposisi mendapatkan skor 227 dengan persentase 75,7 masuk dalam kategori sedang. Sehingga komponen aspek internal secara general berada pada kategori sedang dengan persentase $74,3 \%$. Komponen aspek internal dalam kajian ini meliputi administrasi, organisasi dan lingkungan. Variabel administrasi mendapatkan skor 222 dengan persentase 74,0\% dan masuk dalam kategori sedang. Variabel organiasi mendapat skor 186 dengan persentase 77,5\% masuk dalam kategori sedang. Variabel lingkungan mendapat skor 260 dengan persentase 72,2\% masuk dalam kategori sedang. Sehingga komponen aspek eksternal secara general berada kategori sedang dengan persentase $74,5 \%$. Peningkatan taraf implementasi SOP dilakukan dengan kegiatan pemberdayaan pada indikator terendah divariabel sumberdaya yaitu pemupukan dengan persentase 28,3\%. Pemberdayaan dilakukan dengan materi pengolahan pupuk organik limbah rumah tangga. Terjadi peningkatan perilaku sasaran pengetahuan $(93,3 \%)$, sikap $(85,0 \%)$, dan keterampilan $(75,0 \%)$.
\end{abstract}

Kata Kunci : Implementasi, Pengembangan, Salak, SOP

\section{Abstract}

This study aims to determine the components of the Internal, External aspects and the development of SOP implementation levels in organic salak pondoh cultivation in the Kusuma Mulya Farmers Group, Girikerto District. This study was conducted from March to June 2021 at the Kusuma Mulya Farmers Group, Giriketo Village, Kapanewon Turi, Sleman Regency. Determination of research objects from the district to the village was selected purposively, while the respondents were determined using a saturated sample. There were 20 respondents in this study which 15 were the main respondents and 5 were the supporting respondents. Data collection techniques using deep interviews, questionnaires and focus group discussions. The data analysis technique used descriptive analysis and a modified Likert scale because the research is mixed method. Based on the results of the study the Internal aspects of this study include Resources, Communication and 
Prosiding Seminar Nasional Pembangunan dan Pendidikan Vokasi Pertanian

Politeknik Pembangunan Pertanian Manokwari, 31 Juli 2021

e ISSN : 2774-1982

DOI : https://doi.org/10.47687/snppvp.v2i1.173

Disposition. For the resource variable, it gets a score of 825 with a percentage of $65.5 \%$ means its medium category. Communication variable gets a score of 196 with a percentage of $81.7 \%$ it means high category. Disposition variable gets a score of 227 with a percentage of 75.7 it means medium category. So that the components of the Internal Aspects are generally in the medium category with a percentage of $74.3 \%$. Internal Aspect components in this study include Administration, Organization and Environment. Administration variable gets a score of 222 with a percentage of $74.0 \%$ its categorized medium level. Organizational variable got a score of 186 with a percentage of $77.5 \%$ its categorized medium level. Environmental variable got a score of 260 with a percentage of $72.2 \%$ its categorized medium level. So that the components of the External Aspects are generally in the moderate category with a percentage of $74.5 \%$. Increasing the level of SOP implementation is carried out by empowering activities on the lowest indicator in the resource variable, namely fertilization with a percentage of $28.3 \%$. Empowerment is carried out by using household waste organic fertilizer processing materials. There showed an increase in knowledge target behavior (93.3\%), Attitudes (85.0\%), and Skills (75.0\%).

Keywords: Development, Implementation, Salak, SOP

\section{PENDAHULUAN}

Indonesia merupakan negara yang mempunyai kekayaan sumber daya alam maupun sumber daya manusia yang luar biasa. Berintrinsik dari kondisi ini menjadikan Indonesia menjadi negara yang sangat potensial dalam menunjang kegiatan pembangunan yang berkelanjutan di semua sektor kehidupan. Dalam menunjang kegiatan pembangunan pertanian dalam segala sektor baik pangan maupun hortikultura, berbagai macam cara dan sistem tanam dalam kegiatan budidaya terus dikembangkan untuk memberikan kualitas dan kuantitas yang optimal sehingga dapat meningkatkan perekonomian dalam sektor pertanian.

Beberapa kondisi yang krusial berkaitan dengan kegiatan impor dan ekspor adalah kualitas produk pertanian pada beberapa tingkat yang belum memenuhi persyaratan pada negara tujuan. Perlunya ada peningkatan penerapan terhadap standar operasional prosedur (SOP) dalam kegiatan budidaya agar produk dari sektor pertanian yang berasal dari Indonesia bisa memasuki pasar global. (Rivai, 2011).

Secara general penerapan standar operasional prosedur (SOP) menupakan pedoman budidaya yang langsung direkomendasikan oleh Food Agricultural Organization (FAO). Dalam hal ini bahan atau produk pangan yang dapat memasuki pasar ekspor dan impor adalah yang dibudidayakan dengan menerapkan Standar Operasional Prosedur atau SOP. Standar Operasional Prosedur (SOP) adalah cara pelaksanaan budi daya tanaman pertanian (pangan, buah dan sayur) dan perkebunan secara baik, benar dan tepat, dengan adanya penerapan Standar Operasional Prosedur dalam kegiatan budidaya diharapkan 
Prosiding Seminar Nasional Pembangunan dan Pendidikan Vokasi Pertanian

Politeknik Pembangunan Pertanian Manokwari, 31 Juli 2021

e ISSN : 2774-1982

DOI : https://doi.org/10.47687/snppvp.v2i1.173

mampu menghasilkan kualitas produk yang terjamin kualitas serta aman dari residu residu bahan yang berbahaya pada saat dikonsumsi nantinya.

Tanaman buah salak atau dikenal dengan nama latin Salacca edulis atau Salacca zalacca merupakan salah satu komoditas hortikultura tanaman buah yang cukup endemik di wilayah Indonesia. Kelurahan Girikerto merupakan salah satu kelurahan yang ada di Kapanewon Turi kabupaten Sleman yang merupakan sentra kelompok tani yang membudidayakan tanaman salak secara organik. Sistem yang diterapkan dalam kegiatan budidaya salak organik ini tentunya sudah berasaskan sesuai dengan kebijakan dan ketentuan yang dicanangkan oleh Food Agriculture Organization (FAO). Berdasarkan basis sistem pertanian organik yang sudah diimplementasikan dalam kegiatan budidaya salah ini diharapkan mampu meningkatkan kualitas buah salak sehingga dapat memasuki pangsa pasar yang lebih luas baik dalam tingkat regional maupun internasional. Sehingga secara garis besar penurunan kualitas dan kuantitas terhadap komoditas salak dapat diselesaikan dengan menerapkan komponen-komponen yang ada di dalam Standar Operasional Prosedur (SOP) (Shoffiyati, 2019).

Berdasarkan data sekunder lapangan, kondisi faktual menyatakan terjadi penurunan jumlah produksi yang sangat signifikan dari tahun 2018 hingga tahun 2019 (1 tahun) yang diperkirakan penurunan sampai 65\% dari total produksi tahun 2018 yang mencapai 902.995 kuintal menjadi 411.998 kuintal pada tahun 2019 (BPS, 2019). Bahkan untuk Salak pondoh organik sendiri terjadi penurunan yang sangat signifikan $19.919(\mathrm{~kg})$ tahun 2018, $15.922(\mathrm{~kg})$ tahun 2019, dan 5.167 (kg) pada tahun 2020 (Data Primer, 2020). Salah satu faktor yang menyebabkan degradasi produksi yang cukup signifkan ini disebabkan oleh degradasi mutu lingkungan dan standarisasi operasi dalam budidaya. Berdasarkan analisis masalah dari latar belakang tersebut maka penulis melakukan kajian komoditas salak dengan judul "Pengembangan Implementasi SOP (Standar Operasional Prosedur) Budidaya Salak Pondoh (Salacca edulis) Organik studi kasus Kelompok Tani Kusuma Kalurahan Girikerto Kapanewon Turi Kabupaten Sleman Daerah Istimewa Yogyakarta (DIY)".

Tujuan penelitian ini untuk mengetahui komponen aspek internal dan eksternal pengembangan Implementasi SOP dalam budidaya Salak Pondoh (Salacca edulis) serta meningkatkan pengembangan taraf implementasi SOP (Standar Operasional Prosedur) dalam optimalisasi kegiatan Budidaya Salak Pondoh (Salacca edulis) Organik. 
Prosiding Seminar Nasional Pembangunan dan Pendidikan Vokasi Pertanian

Politeknik Pembangunan Pertanian Manokwari, 31 Juli 2021

e ISSN : 2774-1982

DOI : https://doi.org/10.47687/snppvp.v2i1.173

\section{METODE}

Metode yang digunakan dalam penilitian ini adalah metode penelitian kombinasi (mix method). Menurut Sugiyono (2018), metode penelitian kombinasi merupakan metode yang menggabungkan antara metode kuantitatif dan metode kualitatif. Model metode kombinasi yang akan digunakan adalah current triangulation strategy yang mana merupakan penggabungan metode kuantitatif dan kualitatif secara bersamaan, kemudian dapat ditentukan mana data yang bisa digabungkan ataupun dibedakan pada saat pengolahan data nantinya. Penggabungan data dilakukan pada penyajian data, interpretasi dan membuat kesimpulan dari data yang ditampilkan. Bobot nilai yang akan ditampilkan pada penyajian data bisa saja mempunyai hasil yang berbeda dari kedua metode ini, hal ini dikarenakan setiap variabel akan memberikan variasi data yang berbeda.

Penentuan objek penelitian mulai dari kabupaten hingga desa dipilih secara purposive, sedangkan untuk responden ditentukan menggunakan sampel jenuh. Terdapat 20 responden dalam kajian ini dimana 15 orang sebagai responden utama dan 5 orang sebagai responden pendukung. Teknik pengumpulan data menggunakan Indeepth interview, kuesioner dan focus group discussion. Teknik analisis data menggunakan analisis desktiptif dan skala likert modifikasi karena penelitian berupa penelitian gabungan (mix method).

\section{HASIL DAN PEMBAHASAN}

\section{Gambaran Umum Wilayah}

Girikerto merupakan salah satu kelurahan di Kapanewon Turi, Kebupaten Sleman, provinsi Daerah Istimewa Yogyakarta. Awal mulanya kelurahan Girikerto merupakan wilayah yang terdiri dari 4 (empat) Kelurahan yaitu kelurahan Tanggung, kelurahan Ngandong, kelurahan Nangsri Lor, dan kelurahan Kemirikebo. Berdasarkan maklumat Pemerintah Daerah Istimewa Yogyakarta pada tahun 1946 mengenai Pemerintahan Kelurahan, maka kelurahan tersebut digabung menjadi satu kelurahan otonom yaitu kelurahan Girikerto. Kelurahan Girikerto merupakan wilayah agraris yang subur dengan luas wilayah 1.002.9726 Ha, dengan batas wilayah sebagai berikut :

$\begin{array}{ll}\text { - } & \text { Sebelah Utara } \\ \text { - } & \text { Sebelah Timur } \\ \text { - } & \text { Sebelah Selatan } \\ \text { - } & \text { Sebelah Barat }\end{array}$
: Hutan Lindung Merapi

: Kalurahan Purwobinangun, Kapanewon Pakem

: Kalurahan Donokerto, Kapanewon Turi

: Kalurahan Wonokerto, Kapanewon Turi 
Prosiding Seminar Nasional Pembangunan dan Pendidikan Vokasi Pertanian

Politeknik Pembangunan Pertanian Manokwari, 31 Juli 2021

e ISSN : 2774-1982

DOI : https://doi.org/10.47687/snppvp.v2i1.173

Tabel 1. Penggunaan Tanah Warga

\begin{tabular}{|c|c|c|}
\hline No & Jenis Peruntukan Tanah & Luas (Ha) \\
\hline 1 & Sawah & 277,5475 \\
\hline 2 & Tegal & 388,9425 \\
\hline 3 & Pekarangan & 261,356 \\
\hline Total & & 6.926 .256 \\
\hline
\end{tabular}

Sumber : Data Primer 2021

Ketinggian dari permukaan air laut $\pm 400-800 \mathrm{~m}$ dengan kemiringan sekitar $30^{\circ}$. Pola penggunaan lahan di kelurahan Girikerto lebih didominasi oleh kegiatan pertanian terutama salak dan padi. Secara umum kondisi hidrologi wilayah kelurahan Girikerto terbagi dalam dua kondisi yaitu wilayah kering dan wilayah basah. Wilayah kering yang dimaksud tidak memiliki sungai permanen, meliputi 3 (tiga) padukuhan bagian utara yaitu Ngandong, Kemirikebo, dan Nganggring. Wilayah ini memiliki sumber mata air, tetapi kondisi morfologi dan topografinya tidak dapat mengalir ke daerahnya sendiri, sehingga saat musim kemarau sering terjadi kekeringan. Secara geologi wilayah kelurahan Girikerto merupakan daerah lereng di kaki Gunung Merapi yang secara keseluruhan permukaannya tersusun oleh endapan vulkanik Gunung Merapi yang telah mengalami pelapukan rendah sampai tinggi. Kelurahan Girikerto mempunyai kondisi tanah yang subur dan memungkinkan segala jenis tanaman tumbuh dengan baik. Selain salak pondoh, yang menjadi komoditas utama, sayuran, buah-buahan, dan berbagai tanaman keras tumbuh dengan baik.

\section{Hasil Analisis Data}

\section{Aspek Internal}

Aspek Internal adalah bagaimana faktor-faktor dalam setiap variabel pengukuran yang tentunya berasal dari dalam diri responden atau petani itu sendiri. Dalam hal ini aspek internal terbagi menjadi beberapa variabel sesuai dengan peruntukannya. Adapun rekapitulasi data Aspek Internal dapat dilihat pada tabel 2 sebagai berikut :

Tabel 2. Rekapitulasi Aspek Internal

\begin{tabular}{llcccc}
\hline No & $\begin{array}{c}\text { Variabel } \\
\text { Internal }\end{array}$ & $\begin{array}{c}\text { Nilai } \\
\text { Pencapaian }\end{array}$ & $\begin{array}{c}\text { Nilai Skor } \\
\text { Maksimal }\end{array}$ & $\begin{array}{c}\text { Persentase } \\
(\mathbf{\%})\end{array}$ & Kategori \\
\hline 1 & Sumber Daya & 825 & 1260 & $65,5 \%$ & Sedang \\
2 & Komunikasi & 196 & 240 & $81,7 \%$ & Tinggi \\
3 & Disposisi & 227 & 300 & $75,7 \%$ & Sedang \\
\hline & Jumlah & $\mathbf{1 2 4 8}$ & $\mathbf{1 8 0 0}$ & $\mathbf{7 4 , 3 \%}$ & Sedang \\
\hline
\end{tabular}

Sumber: Data Primer 2021 
Prosiding Seminar Nasional Pembangunan dan Pendidikan Vokasi Pertanian

Politeknik Pembangunan Pertanian Manokwari, 31 Juli 2021

e ISSN : 2774-1982

DOI : https://doi.org/10.47687/snppvp.v2i1.173

Berdasarkan data yang disajikan pada tabel 2 dapat dilihat bahwa variabel sumber daya berada pada nilai capaian 825 dari nilai maksimal 1260 dengan persentase 65,5\% sehingga termasuk dalam kategori sedang. Variabel komunikasi mendapatkatkan nilai pencapaian dengan jumlah 196 dari skor maksimal 240 dengan persentase 81,7\% sehingga termasuk dalam kategori tinggi. Variabel disposisi mendapatkan nilai pencapaian dengan jumlah 227 dari skor maksimal 300 dengan persentase 75,7\% sehingga termasuk dalam kategori sedang. Berdasarkan jumlah secara general dari ketiga variabel yang ada pada aspek internal dengan jumlah capaian 1248 dari total skor 1800 dengan persentase $74,3 \%$ sehingga bisa disimpulkan aspek internal termasuk dalam kategori sedang.

\section{Variabel Sumber daya}

Variabel sumberdaya adalah variabel yang memuat seluruh komponen dalam teknis budidaya Salak Pondoh organik sesuai SOP Budidaya yang telah ditetapkan oleh Dinas Pertanian sebagai acuan dan dilakukan komparasi dengan SOP yang dijadikan pedoman oleh kelompok tani Kusuma Mulya. Adapun rekapitulasi data pada variabel sumber daya dapat dilihat pada tabel 3 sebagai berikut :

Tabel 3. Rekapitulasi Variabel Sumber Daya

\begin{tabular}{ccccc}
\hline No & $\begin{array}{c}\text { Interval } \\
\text { Kelas }\end{array}$ & $\begin{array}{c}\text { Kategori } \\
\text { Variabel }\end{array}$ & $\begin{array}{c}\text { Jumlah } \\
\text { (Orang) }\end{array}$ & $\begin{array}{c}\text { Persentase } \\
(\%)\end{array}$ \\
\hline 1 & $77,79 \%-100 \%$ & Tinggi & 0 & $0,0 \%$ \\
2 & $55,56 \%-77,78 \%$ & Sedang & 15 & $100 \%$ \\
3 & $33,33 \%-55,55 \%$ & Rendah & 0 & $0,0 \%$ \\
\hline \multicolumn{2}{r}{ Jumlah } & & $\mathbf{1 5}$ & $\mathbf{1 0 0 \%}$ \\
\hline
\end{tabular}

Sumber: Data Primer 2021

Berdasarkan data yang disajikan pada tabel 3 variabel sumberdaya berada pada kategori sedang karena terdapat pada rentang interval kelas 55,56 - 77,78\% dengan jumlah responden sebanyak 15 orang. Dilihat dari persentase kategori dari keseluruhan jumlah responden mencapai persentase $100 \%$. Berada pada kategori sedang bukan jaminan semua komponen indikator dalam variabel sumberdaya terlaksana dan diimplementasikan dengan baik. Hal ini dikarenakan pada beberapa kondisi setiap mempunyai komponen indikator yang berkaitan dengan variabel lainnya. Sehingga untuk memberikan keputusan final nantinya harus mengkonparasi dari keseluruhan variabel yang ada. 
Prosiding Seminar Nasional Pembangunan dan Pendidikan Vokasi Pertanian

Politeknik Pembangunan Pertanian Manokwari, 31 Juli 2021

e ISSN : 2774-1982

DOI : https://doi.org/10.47687/snppvp.v2i1.173

\section{Variabel Komunikasi}

Variabel komunikasi berkaitan dengan proses komunikasi sosial yang terjadi dan dilakukan oleh responden baik sesama anggota kelompok tani ataupun dengan pihak lainnya. Dengan adanya pembangunan komunikasi yang baik diharapkan mampu menunjang implementasi SOP dalam budidaya salak organik. Adapun Rekapitulasi variabel komunikasi dapat dilihat pada tabel 4 sebagai berikut :

Tabel 4. Rekapitulasi Variabel Komunikasi

\begin{tabular}{ccccc}
\hline No & $\begin{array}{c}\text { Interval } \\
\text { Kelas }\end{array}$ & $\begin{array}{c}\text { Kategori } \\
\text { Variabel }\end{array}$ & $\begin{array}{c}\text { Jumlah } \\
\text { (Orang) }\end{array}$ & $\begin{array}{c}\text { Persentase } \\
(\boldsymbol{\%})\end{array}$ \\
\hline 1 & $77,79 \%-100 \%$ & Tinggi & 12 & $80 \%$ \\
2 & $55,56 \%-77,78 \%$ & Sedang & 3 & $20 \%$ \\
3 & $33,33 \%-55,55 \%$ & Rendah & 0 & $0,0 \%$ \\
\hline \multicolumn{2}{r}{ Jumlah } & & $\mathbf{1 5}$ & $\mathbf{1 0 0 \%}$ \\
\hline
\end{tabular}

Sumber: Data Primer 2021

Berdasarkan data yang disajikan pada tabel 4 bisa dilihat bahwa sebanyak 12 orang termasuk dalam kategori tinggi dengan persentase $80 \%$ dari total keseluruhan responden. Kemudian 3 orang berada pada kategori sedang dengan persentase $20 \%$ dari total keseluruhan responden.

Menurut Bahri (2018) Komunikasi memberikan peranan yang sangat penting dalam suatu interaksi sosial, oleh karena itu berpengaruh dalam dunia kerja. Dengan terbangunnya komunikasi yang baik pada setiap responden diharapkan mampu menangkap informasi dengan lebih baik juga tentunya.

\section{Variabel Disposisi}

Variabel disposisi berkaitan dengan sikap atau perilaku responden yang akan mempengaruhi proses implementasi SOP.

Tabel 5. Rekapitulasi Variabel Disposisi

\begin{tabular}{ccccc}
\hline No & $\begin{array}{c}\text { Interval } \\
\text { Kelas }\end{array}$ & $\begin{array}{c}\text { Kategori } \\
\text { Variabel }\end{array}$ & $\begin{array}{c}\text { Jumlah } \\
\text { (Orang) }\end{array}$ & $\begin{array}{c}\text { Persentase } \\
(\mathbf{\%})\end{array}$ \\
\hline 1 & $77,79 \%-100 \%$ & Tinggi & 7 & $47 \%$ \\
2 & $55,56 \%-77,78 \%$ & Sedang & 8 & $53 \%$ \\
3 & $33,33 \%-55,55 \%$ & Rendah & 0 & $0,0 \%$ \\
\hline \multicolumn{2}{r}{ Jumlah } & & $\mathbf{1 5}$ & $\mathbf{1 0 0 \%}$ \\
\hline
\end{tabular}

Sumber: Data Primer 2021

Berdasarkan data yang disajikan pada tabel 5 bisa dilihat yaitu sebanyak 7 orang responden berada pada kategori tinggi dengan persentase $47 \%$ dari total keseluruhan 
Prosiding Seminar Nasional Pembangunan dan Pendidikan Vokasi Pertanian

Politeknik Pembangunan Pertanian Manokwari, 31 Juli 2021

e ISSN : 2774-1982

DOI : https://doi.org/10.47687/snppvp.v2i1.173

responden. Kemudian terdapat 8 responden yang berada pada kategori sedang dengan persentase $53 \%$ dari total keseluruhan responden.

\section{Aspek Eksternal}

Adalah bagaimana faktor-faktor dalam setiap variabel pengukuran yang tentunya berasal dari luar diri responden atau petani itu sendiri. Dalam hal ini aspek eksternal terbagi menjadi beberapa variabel sesuai dengan peruntukannya. Adapun rekapitulasi data aspek internal dapat dilihat pada tabel 6 sebagai berikut :

Tabel 6. Rekapitulasi Aspek Eksternal

\begin{tabular}{cccccc}
\hline No & $\begin{array}{c}\text { Variabel } \\
\text { Internal }\end{array}$ & $\begin{array}{c}\text { Nilai } \\
\text { Pencapaian }\end{array}$ & $\begin{array}{c}\text { Nilai Skor } \\
\text { Maksimal }\end{array}$ & $\begin{array}{c}\text { Persentase } \\
(\mathbf{\%})\end{array}$ & Kategori \\
\hline 1 & Administrasi & 222 & 300 & $74,0 \%$ & Sedang \\
2 & Organisasi & 186 & 240 & $77,5 \%$ & Sedang \\
3 & Lingkungan & 260 & 360 & $72,2 \%$ & Sedang \\
\hline & Jumlah & $\mathbf{1 2 4 8}$ & $\mathbf{1 8 0 0}$ & $\mathbf{7 4 , 5 \%}$ & Sedang \\
\hline
\end{tabular}

Sumber: Data Primer 2021

Berdasarkan data yang disajikan pada tabel 6 yaitu variabel administrasi mendapatkan nilai capai 222 dari skor maksimal 300 dengan persentase 74,0\% dan masuk dalam kategori sedang. Variabel organisasi atau pengorganisasian mendapat nilai capaian 186 dari skor maksimal 240 dengan persentase 77,5\% dan masuk dalam kategori sedang. Variabel lingkungan mendapat nilai capaian 260 dari skor maksimal 360 dengan persentase 72,2\% masuk dalam kategori sedang. Dengan demikian dapat disimpulkan bahwa aspek eksternal secara general berada pada kategori sedang dengan persentase $74,5 \%$.

\section{Variabel Administrasi}

Secara general administrasi biasanya hanya dikaitkan dengan pencatatan dan pemberkasan saja, meskipun demikian dalam budidaya organik administrasi mempunyai peranan yang sangat penting dan kompleks yang berkaitan dengan sertifikasi organik. Rekapitulasi variabel administrasi dapat dilihat pada tabel 7 sebagai berikut :

Tabel 7. Rekapitulasi Variabel Administrasi

\begin{tabular}{ccccc}
\hline No & $\begin{array}{c}\text { Interval } \\
\text { Kelas }\end{array}$ & $\begin{array}{c}\text { Kategori } \\
\text { Variabel }\end{array}$ & $\begin{array}{c}\text { Jumlah } \\
\text { (Orang) }\end{array}$ & $\begin{array}{c}\text { Persentase } \\
(\boldsymbol{\%})\end{array}$ \\
\hline 1 & $77,79 \%-100 \%$ & Tinggi & 4 & $26 \%$ \\
2 & $55,56 \%-77,78 \%$ & Sedang & 11 & $73 \%$ \\
3 & $33,33 \%-55,55 \%$ & Rendah & 0 & $0,0 \%$ \\
\hline \multicolumn{2}{r}{ Jumlah } & & $\mathbf{1 5}$ & $\mathbf{1 0 0 \%}$ \\
\hline
\end{tabular}

Sumber: Data Primer 2021 
Prosiding Seminar Nasional Pembangunan dan Pendidikan Vokasi Pertanian

Politeknik Pembangunan Pertanian Manokwari, 31 Juli 2021

e ISSN : 2774-1982

DOI : https://doi.org/10.47687/snppvp.v2i1.173

Berdasarkan data yang disajikan pada tabel 7 dapat dilihat bahwa pada variabel administrasi terdapat sebanyak 4 orang berada pada kategori tinggi dengan persentase $26 \%$ dari total keseluruhan responden. Kemudian sisanya yaitu 11 orang berada pada kategori sedang dengan persentase $73 \%$ dari total keseluruhan responden.

\section{Variabel Organisasi}

Variabel organisasi adalah indikator yang berkaitan dengan pengorganisasian baik terkait pengorganisasian internal maupun eskternal. Rekapitulasi variabel organisasi dapat dilihat pada tabel 8 sebagai berikut

Tabel 8. Rekapitulasi Variabel Organisasi

\begin{tabular}{ccccc}
\hline No & $\begin{array}{c}\text { Interval } \\
\text { Kelas }\end{array}$ & $\begin{array}{c}\text { Kategori } \\
\text { Variabel }\end{array}$ & $\begin{array}{c}\text { Jumlah } \\
\text { (Orang) }\end{array}$ & $\begin{array}{c}\text { Persentase } \\
(\mathbf{\%})\end{array}$ \\
\hline 1 & $77,79 \%-100 \%$ & Tinggi & 6 & $40 \%$ \\
2 & $55,56 \%-77,78 \%$ & Sedang & 9 & $60 \%$ \\
3 & $33,33 \%-55,55 \%$ & Rendah & 0 & $0,0 \%$ \\
\hline \multicolumn{2}{r}{ Jumlah } & & $\mathbf{1 5}$ & $\mathbf{1 0 0 \%}$ \\
\hline
\end{tabular}

Sumber: Data Primer 2021

Berdasarkan data yang disajikan pada tabel 8 dapat dilihat bahwa pada variabel organisasi ini terdapat 6 orang responden yang berada pada kategori tinggi dengan persentase $40 \%$ dari total keseluruhan responden. Kemudian terdapat 9 orang responden yang berada pada kategori sedang dengan persentase $60 \%$ dari total keseluruhan responden.

\section{Variabel Lingkungan}

Variabel lingkungan adalah variabel yang berkaitan dengan kondisi dan kesehatan alam maupun pemilihan komoditas yang akan memberikan dampak secara langsung terhadap implementasi SOP budidaya. Rekapitulasi variabel lingkungan dapat dilihat pada tabel 9 sebagai berikut :

Tabel 9. Rekapitulasi Variabel Lingkungan

\begin{tabular}{ccccc}
\hline No & $\begin{array}{c}\text { Interval } \\
\text { Kelas }\end{array}$ & $\begin{array}{c}\text { Kategori } \\
\text { Variabel }\end{array}$ & $\begin{array}{c}\text { Jumlah } \\
\text { (Orang) }\end{array}$ & $\begin{array}{c}\text { Persentase } \\
(\mathbf{\%})\end{array}$ \\
\hline 1 & $77,79 \%-100 \%$ & Tinggi & 5 & $33 \%$ \\
2 & $55,56 \%-77,78 \%$ & Sedang & 10 & $67 \%$ \\
3 & $33,33 \%-55,55 \%$ & Rendah & 0 & $0,0 \%$ \\
\hline \multicolumn{2}{r}{ Jumlah } & & $\mathbf{1 5}$ & $\mathbf{1 0 0 \%}$ \\
\hline
\end{tabular}

Sumber: Data Primer 2021

Berdasarkan data yang disajikan pada tabel 9 dapat dilihat bahwa pada variabel lingkungan terdapat 5 orang responden yang termasuk dalam kategori tinggi dengan 
Prosiding Seminar Nasional Pembangunan dan Pendidikan Vokasi Pertanian

Politeknik Pembangunan Pertanian Manokwari, 31 Juli 2021

e ISSN : 2774-1982

DOI : https://doi.org/10.47687/snppvp.v2i1.173

persentase $33 \%$ dari total responden. Kemudian terdapat 10 orang masuk dalam kategori sedang dengan persentase $67 \%$ dari total keseluruhan responden.

\section{Pengambilan Keputusan Hasil Kajian}

Pengambilan keputusan menjadi langkah akhir dalam kajian ini. Proses mulai dari pengambilan data hingga pengambilan keputusan selalu mempertimbangkan partisipasi dari sasaran kajian ini yang responden melalui FGD.

Metode mengambil keputusan secara bersama melalui diskusi ini diharapkan mampu memerikan ketetapatan terhadap hasil kajian, hal ini dikarenakan hasil kajian ini nantinya akan menjadi acuan dalam kegiatan pemberdayaan. Proses pengambilan keputusan dilakukan dengan perengkingan pada setiap variabel pada aspek internal dan eksternal didiskusikan berdasarkan pemikiran-pemikiran logis dan beracuan pada kondisi lapangan dan sosial yang dirasakan langsung oleh responden. Adapun hasil kegiatan perengkingan dapat dilihat pada tabel 10 sebagai berikut :

Tabel 10. Perengkingan Hasil Kajian melalui FGD

\begin{tabular}{llcc}
\hline No & $\begin{array}{c}\text { Indikator } \\
\text { Variabel }\end{array}$ & $\begin{array}{c}\text { Persentase } \\
(\boldsymbol{\%})\end{array}$ & $\begin{array}{c}\text { Rangking } \\
\text { (Prioritas) }\end{array}$ \\
\hline 1 & Pemupukan Susulan & $30,0 \%$ & 2 \\
2 & Teknik Pemupukan Susulan & $28,3 \%$ & 4 \\
3 & Ketersediaan Pupuk & $28,3 \%$ & 1 \\
4 & Jadwal pemupukan & $31,7 \%$ & 3 \\
5 & Penggunaan IT dalam Administrasi & $46,7 \%$ & 8 \\
6 & Pergantian Komoditas & $55,0 \%$ & 5 \\
7 & Komitmen Implementasi & $53,3 \%$ & 7 \\
8 & Tingkat Kepentingan SOP & $48,3 \%$ & 6 \\
\hline Sumber: Data Primer 2021
\end{tabular}

Sumber: Data Primer 2021

\section{Pembahasan}

Pengembangan implementasi SOP dalam budidaya salak pondoh organik adalah pengembangan yang diharapkan yaitu dengan adanya peningkatan secara kualitas dari segala komponen yang ada pada standar operasional prosedur budidaya. Dalam hal ini pengembangan implementasi dalam SOP budidaya diukur berdasarkan aspek internal dan eksternal. Aspek internal dan aspek eksternal dalam kajian ini merupakan variabel secara general yang akan di ukur untuk mengetahui tingkat implementasi sop budidaya. Untuk aspek internal sendiri terdiri dari variabel sumber daya, komunikasi, dan disposisi. Sedangkan untuk variabel eksternal terdiri dari administrasi, organisasi, dan lingkungan. 
Prosiding Seminar Nasional Pembangunan dan Pendidikan Vokasi Pertanian

Politeknik Pembangunan Pertanian Manokwari, 31 Juli 2021

e ISSN : 2774-1982

DOI : https://doi.org/10.47687/snppvp.v2i1.173

\section{Aspek Internal}

Secara general berdasarkan hasil analisis aspek internal berada pada kategori sedang Hal ini dikarenakankan dari masing-masing variabel juga berada pada kategori sedang. Dilihat dari keseluruhan aspek internal variabel sumber daya mendapat presentasi terendah di antara ketiga variabel yang ada. Hal ini dikarenakan variabel sumber daya adalah variabel yang memuat indikator tentang keseluruhan teknis budidaya. Dalam variabel sumberdaya ini memuat kegiatan-kegiatan yang harus dilakukan selama kegiatan budidaya mulai dari penyiapan bibit dan pengolahan tanah hingga pascapanen berupa sortasi dan grading.

\section{Variabel Sumber Daya}

Padahal variabel sumber daya rekapitulasi berdasarkan responden yaitu terdapat 15 responden yang berada pada kategori sedang dalam implementasi variabel sumber daya. Hal ini dikarenakan pada hakikatnya nya seluruh responden sudah mengetahui keseluruhan komponen atau indikator yang harus diterapkan dalam budidaya salak organik. Namun yang di penyebab masih termasuk dalam kategori sedang karena pada beberapa apa indikator masih kurang komitmen atau implementasi dari segi kualitas.

Berdasarkan data yang ditampilkan pada hasil analisis indikator variabel sumber daya terdapat 21 indikator dalam variabel ini. Kemudian apabila kita melihat dari perhitungan persentase yang ada terdapat beberapa indikator dengan presentasi terendah yaitu indikator pemupukan susulan, teknik pemupukan susulan, ketersediaan pupuk, dan jadwal pemupukan. Untuk menghubungkan susulan sendiri sebenarnya harus dilakukan sesuai dengan ketentuan yang ada karena hal ini akan berkaitan dengan ketersediaan unsur hara yang ada di dalam tanah. Kemudian untuk teknik yang digunakan dalam teknik pemupukan susulan belum sesuai dengan ketentuan yang ada pada SOP dimana pada SOP yang disusun oleh kelompok tani dan dinas pertanian pemupukan dianjurkan dengan cara dibenamkan pada sekeliling tanaman dengan menggunakan ukuran lebar tajuk tanaman dengan kedalaman kurang lebih $15 \mathrm{~cm}$ di dalam tanah akan tetapi pada kenyataannya di lapangan hanya beberapa responden yang melakukan pemupukan dengan teknik yang dianjurkan oleh SOP.

Kemudian untuk ketersediaan pupuk beberapa responden memenuhi kebutuhan pupuk dengan cara membeli pada kelompok ternak yang ada di wilayah kelurahan Girikerto, kemudian beberapa responden lainnya itu menggunakan milik sendiri karena memang mempunyai ternak sendiri. Meskipun kadang ada juga bantuan dari pemerintah 
Prosiding Seminar Nasional Pembangunan dan Pendidikan Vokasi Pertanian

Politeknik Pembangunan Pertanian Manokwari, 31 Juli 2021

e ISSN : 2774-1982

DOI : https://doi.org/10.47687/snppvp.v2i1.173

ataupun asosiasi tetapi ketersediaan pupuk belum terpenuhi secara keseluruhan. Disamping itu harga pupuk organik yang dijual oleh kelompok ternak juga termasuk pada range harga yang cukup tinggi yaitu berkisar antara Rp. 30.000 sampai Rp 40.000 untuk 1 sak karung. Kemudian untuk jadwal pemupukan sendiri, ketentuan yang diatur oleh SOP dilakukan sebanyak 2 kali dalam kurun waktu 1 tahun yaitu pada awal musim hujan dan akhir musim penghujan menuju musim kemarau. Akan tetapi fakta di lapangan kebanyakan responden hanya melakukan pengumpulan satu kali bahkan ada yang tidak pernah melakukan pemupukan selama kurun waktu 2 tahun.

Untuk indikator-indikator yang berada pada kategori sedang ke depannya harus ditingkatkan karena apabila tidak dilakukan peningkatan implementasi bisa saja terjadi penurunan terhadap indikator lainnya. Mengapa peningkatan implementasi dalam aspek sumber daya ini sangat penting hal ini berdasarkan penelitian sebelumnya dimana Menurut Handayani et al. (2018) pengembangan usaha tani salak pondoh dapat dilakukan dengan memaksimalkan pelaksanaan kegiatan budidaya yang baik dengan penerapan SOP dan GAP budidaya serta upaya peningkatan kapasitas keterampilan budidaya patani.

Berkaitan dengan penelitian ini, artinya kompetensi petani dalam menerapkan SOP baik dari segi kualitas maupun kuatitas akan menentukan tingkat keberlanjutan usaha tani serta menjadi indikator utama dalam pengembangan implementasi SOP. Penerapan SOP maupun GAP dalam kegiatan budidaya merupakan komponen yang sangat penting apalagi dalam ranah produk dengan klaim organik.

\section{Variabel Komunikasi}

Pada variabel komunikasi terdapat 12 responden yang berada pada kategori tinggi dan 3 responden yang berada pada kategori sedang. Hal ini dapat kita simpulkan bahwa secara general responden sudah membangun komunikasi yang bagus baik antara anggota kelompok tani ataupun dengan pihak lainnya yang berkaitan dengan responden. Berdasarkan hasil analisis indikator variabel komunikasi itu terdapat 4 indikator di dalamnya yang masing-masing sudah mempunyai persentase implementasi yang masuk dalam kategori yang tinggi. Indikator yang pertama ada diskusi internal diskusi internal di sini sudah sangat berjalan dengan baik hal bisa dilihat dengan rutinitas yang dilakukan melalui pertemuan rutin setiap minggunya hingga saat ini meskipun kondisi pandemi melanda.

Dalam diskusi internal ini tidak hanya dilakukan pada saat pertemuan rutin tetapi juga dilaksanakan ketika ditemukan kesulitan di lapangan baik yang berkaitan dengan 
Prosiding Seminar Nasional Pembangunan dan Pendidikan Vokasi Pertanian

Politeknik Pembangunan Pertanian Manokwari, 31 Juli 2021

e ISSN : 2774-1982

DOI : https://doi.org/10.47687/snppvp.v2i1.173

teknis budidaya ataupun tentang pemasaran. Kemudian untuk indikator variabel komunikasi yang kedua itu adalah internal problem solving atau penyelesaian masalah secara internal sampai saat ini kenapa kelompok tani Kusuma Mulya masih bisa berjalan dengan baik hal ini dikarenakan proses penyelesaian masalah secara internal yang dapat terus diselesaikan dengan baik. Penyelesaian masalah ini bisa dicapai dengan baik tentunya karena setiap responden mampu memberikan tanggung jawab, dan diskusi yang terbuka antar responden lainnya sehingga tidak memunculkan masalah masalah lain dalam internal kelompok.

Dengan demikian kita bisa menyimpulkan bahwa variabel komunikasi dalam aspek internal mempunyai persentase yang tinggi dikarenakan proses pembangunan komunikasi dan penyelesaian masalah dalam kelompok tani Kusuma Mulya sudah berjalan dengan sangat baik. Berkaitan dengan hal ini tentunya sudah sangat sesuai dengan fungsi komunikasi yang termuat dalam Sutono (2017) yaitu proses pembangunan komunikasi yang baik dapat diukur dengan kesesuian fungksi komunikasi yang meliputi fungsi sebagai informasi, motivasi, pengungkapan emosi hingga pengawasan dalam penyampaian informasi. Berkaitan dengan hal ketika komunikasi yang terbangun dengan baik pada responden akan memberikan fungsi yang cukup signifikan terhadap proses pembangunan komunikasi antar kelompok tani. Ketika pembangunan komunikasi ini sudah sesuai dengan fungsinya, akan mempermudah proses kegiatan pemotivasian dalam implementasi SOP dalam budidaya Salak Pondoh organik.

\section{Variabel Disposisi}

Dalam variabel disposisi responden yang berada pada kategori tinggi berjumlah 7 orang sedangkan yang berada pada kategori sedang berjumlah 8 orang. Dalam hal ini cukup krusial karena variabel disposisi berkaitan dengan proses pembentukan perilaku maupun sikap petani terhadap implementasi SOP. Terdapat 5 indikator dalam variabel disposisi yang pertama itu adalah prioritas implementasi SOP yang juga termasuk dalam kategori tinggi hal ini berarti responden sudah menyadari bahwa implementasi SOP merupakan salah satu hal yang harus diprioritaskan dalam kegiatan budidaya.

Kemudian indikator yang kedua yaitu adalah adopsi implementasi SOP juga berada pada kategori tinggi artinya responden sudah bisa mengadopsi teknik-teknik dalam penerapan SOP hal ini bisa dipastikan karena memang responden sudah mempunyai banyak pengalaman dalam melaksanakan SOP yang ada. Untuk indikator variabel selanjutnya adalah tingkat komitmen implementasi yang yang berada pada kategori 
Prosiding Seminar Nasional Pembangunan dan Pendidikan Vokasi Pertanian

Politeknik Pembangunan Pertanian Manokwari, 31 Juli 2021

e ISSN : 2774-1982

DOI : https://doi.org/10.47687/snppvp.v2i1.173

rendah Hal ini disebabkan karena meskipun responden mempunyai motivasi yang tinggi dalam implementasi tetapi komitmen dalam jangka panjang belum terbangun secara keseluruhan sehingga berada pada kategori rendah.

Variabel disposisi ini sangat erat kaitan dengan proses penerimaan dan perilaku petani terhadap implementasi SOP. Berkaitan dengan perubahan perilaku para pakar behaviorisme berpendapat yang termuat dalam Yulianto (2016) perubahan perilaku melalui berbagai proses yang tahapannya antara lain berperilaku, berpengalaman, berkeyakinan, pemapanan pribadi menjadi filosofi personal yang akhirnya perilaku yang selaras. Kemudian proses tahapan yang banyak ini bisas dilalui dan dicapai setelah adanya penanaman nilai-nilai kesadaran dari pengalaman indera, pengalaman kejiwaan mauapun pengalaman religius.

Berkaitan tentang teori kesadaran Wilber membagi kesadaran manusia dalam 4 kuadran yaitu intentional, behavioural, cultural and social (Wilber, 1997). Berdasarkan teori ini responden sudah melalui keseluruhan tahap dalam proses teori kesadaran maupun tahapan perubahan perilaku hanya saja kembali kepada sifat alamiah manusia yang sewaktu-waktu dapat turun intensitas komitmen sehingga perlu adanya tindakan pemotivasian yang dalam hal ini bisa dilakukan oleh personal reponden, rekan seprofesi maupun bantuan pihak lain (fasilitator).

\section{Aspek Eksternal}

Aspek eksternal adalah komponen pengukuran variabel yang tentunya berasal dari luar diri responden atau petani itu sendiri. Berdasarkan hasil rekapitulasi aspek eksternal setiap variabel mulai dari variabel administrasi, variabel organisasi, maupun variabel lingkungan berada pada kategori sedang Hal ini dapat diartikan bahwa secara general responden sudah menjalankan administrasi maupun organisasi sesuai dengan ketentuan begitu juga dengan keterkaitannya terhadap lingkungan tempat budidaya.

\section{Variabel Administrasi}

Berdasarkan hasil rekapitulasi variabel administrasi terdapat 4 responden yang berada pada kategori tinggi dan 11 responden yang berada pada kategori sedang intrinsik dari hal ini bisa kita simpulkan bahwa kegiatan pengadministrasian cukup berjalan dengan bagus pada keseluruhan responden. Dalam variabel administrasi terdapat sebanyak 5 indikator di dalamnya. Indikator dengan persentase tertinggi masuk dalam kategori tinggi terdiri dari indikator sertifikasi organik, korelasi administrasi dengan implementasi SOP, serta kemudahan pencatatan. 
Prosiding Seminar Nasional Pembangunan dan Pendidikan Vokasi Pertanian

Politeknik Pembangunan Pertanian Manokwari, 31 Juli 2021

e ISSN : 2774-1982

DOI : https://doi.org/10.47687/snppvp.v2i1.173

Kemudian untuk indikator yang berada pada kategori sedang yaitu adalah pengisian form kegiatan, meskipun berada pada kategori sedang dengan persentase $56,7 \%$ cukup memprihatinkan mengingat pengisian form kegiatan ini nantinya akan menjadi lampiran ketika akan melakukan kegiatan sertifikasi organik. Kemudian untuk indikator dengan persentasi terendah adalah penggunaan IT dalam administrasi.

Padahal diharapkan kedepannya kemajuan teknologi dapat mempermudah proses pengadministrasian akan tetapi karena terkendala dari sarana dan prasarana ataupun keterampilan dan kemampuan responden sehingga penggunaan teknologi informasi dalam administrasi ini belum bisa diimplementasikan

Berkaitan dengan kegiatan pengadministrasian tidak hanya mempunyai keterkaitan dengan pecatatan dan sejenisnya saja tetapi mempunyai hubungan dengan beberapa faktor lainnya. Menurut Suadnya (2020) penguatan kelembagaan kelompok tani dapat dilakukan dengan pelatihan administrasi dalam mendukung pencapaian kegiatan ekonomi. Artinya dengan pelaksanaan administrasi yang bagus responden akan mampu melaksanakan manajerial dan analisis keuangan yang baik. Berkaitan dengan hal ini, administrasi pada kelompok tani Kusuma Mulya tidak hanya berorientasi pada manajerial dan analisis keuangan akan tetapi menjadi komponen yang penting karena sebagai persyaratan kegiatan serifikasi organik.

\section{Variabel Organisasi}

Berdasarkan hasil rekapitulasi variabel organisasi terdapat 6 responden yang berada pada kategori tinggi dan 9 responden yang berada pada kategori rendah sehingga secara general kita bisa menyimpulkan bahwa proses kegiatan pengorganisasian ataupun pelaksanaan organisasi sudah berjalan dengan sangat baik. Dalam variabel organisasi terdapat empat indikator. Dalam indikator ini terdapat dua indikator yang mempunyai persentase sedang yaitu peranan asosiasi dan penyuluh pertanian serta dinamika dan konflik sosial. Berada pada kategori sedang berarti peranan dan asosiasi serta penyuluh sudah berperan dengan sangat bagus serta proses penyelesaian konflik sosial sudah dilakukan dengan baik akan tetapi masih perlu ditingkatkan lagi. Kemudian 2 indikator lainnya berada pada kategori tinggi yang artinya pelaksanaannya sudah sangat bagus yaitu intensitas pertemuan kelompok dan peranan lembaga pemerintah dan dinas terkait.

Berkaitan dengan pengorganisasian sebenarnya tidak hanya dalam ruang lingkup internal kelompok lainnya akan tetapi juga berasal dari organisasi kelembagaan terkait baik pemerintah maupun dinas terkait. Menurut Ahmar (2016) pemerintah mempunyai 
Prosiding Seminar Nasional Pembangunan dan Pendidikan Vokasi Pertanian

Politeknik Pembangunan Pertanian Manokwari, 31 Juli 2021

e ISSN : 2774-1982

DOI : https://doi.org/10.47687/snppvp.v2i1.173

peranan yang penting dalam pengembangan dan penguatan organisasi dan kelembagaan petani sebagai fasilitator. Fasilitator dalam hal ini bisa didefinisikan sebagai oknum yang akan membantu menyediakan, dan menjebatani segala kegiatan kelompok yang tentunya capaian akhir adalah penguatan kelembagaan kelompok dan keberlanjutan usaha. Berdasarkan kondisi lapangan kelompok tani Kusuma Mulya sudah mendapatan fasiltator yang lengkap baik dari pemerintah seperti bantuan aparat kelurahan maupun pemerintah Kapanewon dan pemerintah kabupaten. Fasilitator sebagai penyapaian informasi dari dinas terkait meliputi BPP, Dinas Pertanian hingga Dinas Perdagangan dengan intensitas peranan yang cukup baik.

\section{Variabel Lingkungan}

Variabel lingkungan adalah variabel dengan urutan terakhir dalam aspek eksternal. Berdasarkan hasil rekapitulasi variabel lingkungan terdapat 5 responden yang berada pada kategori tinggi dan 10 responden yang berada pada kategori sedang belatar belakang dari kondisi ini kita bisa menyimpulkan bahwa hampir keseluruhan responden sudah tahu dan menyadari pentingnya kondisi dan kualitas lingkungan terhadap keberlanjutan usaha tani serta pengaruh implementasi SOP terhadap kualitas dan kesehatan lingkungan.

Kondisi dan kesehatan lingkungan menjadi isu yang krusial baik diwilayah Indonesia maupun dunia. Menurut Kunia (2008) penurunan kualitas lingkungan dapat disebabkan oleh kegiatan pertambangan, emisi gas rumah kaca, pengelolaan limbah industri yang tidak tepat serta budidaya pertanian yang lingkungan. Berkaitan dengan hal ini artinya budidaya organik yang dilaksanakan sesuai dengan ketentuan implementasi SOP secara langsung akan membantu proses peningkatan kualitas lingkungan secara general.

Kelompok tani Kusuma Mulya juga sudah melakukan kegiatan budidaya organik ini dalam kurun waktu yang cukup lama, diharapkan akan menjaga kualitas tanah di wilayah kelurahan Girikerto, mengingat Salak tumbuh dengan optimal pada lokasi dengan Indikasi Geografis (IG) yang sesuai.

\section{KESIMPULAN DAN SARAN}

Berdasarkan hasil kajian komponen aspek internal dalam kajian ini meliputi sumberdaya, komunikasi dan disposisi. Untuk variabel sumberdaya mendapatkan skor 825 dengan persentase $65,5 \%$ dan masuk dalam kategori sedang. Variabel komunikasi mendapatkan skor 196 dengan persentase 81,7\% masuk dalam kategori tinggi. Variabel disposisi mendapatkan skor 227 dengan persentase 75,7 masuk dalam kategori sedang. 
Prosiding Seminar Nasional Pembangunan dan Pendidikan Vokasi Pertanian

Politeknik Pembangunan Pertanian Manokwari, 31 Juli 2021

e ISSN : 2774-1982

DOI : https://doi.org/10.47687/snppvp.v2i1.173

Sehingga komponen aspek internal secara general berada pada kategori sedang dengan persentase $74,3 \%$. Komponen aspek internal dalam kajian ini meliputi administrasi, organisasi dan lingkungan. Variabel administrasi mendapatkan skor 222 dengan persentase $74,0 \%$ dan masuk dalam kategori sedang. Variabel organiasi mendapat skor 186 dengan persentase $77,5 \%$ masuk dalam kategori sedang. Variabel lingkungan mendapat skor 260 dengan persentase $72,2 \%$ masuk dalam kategori sedang. Sehingga komponen aspek eksternal secara general berada kategori sedang dengan persentase $74,5 \%$. Peningkatan taraf implementasi SOP dilakukan dengan kegiatan pemberdayaan pada indikator terendah divariabel sumberdaya yaitu pemupukan dengan persentase 28,3 $\%$. Pemberdayaan dilakukan dengan materi pengolahan pupuk organik limbah rumah tangga. Terjadi peningkatan perilaku sasaran pengetahuan $(93,3 \%)$, sikap $(85,0 \%)$, dan keterampilan $(75,0 \%)$.

\section{DAFTAR PUSTAKA}

Agustina, F., Zahri, I., Yazid, M., \& Yunita. (2017). Strategy in Developing Good Agricultural Practices (GAP) in Bangka Regency, of Bangka Belitung Island Province. Jurnal Ilmu Pertanian Indonesia, 22(2), 133-139. https://doi.org/10.18343/jipi.22.2.133.

Ahmar, M. \& A. Parawangi. (2016). Peran Pemerintah dalam pemberdayaan petani padi di Desa Parumpanai Kecamatan Wasuponda Kabupaten Luwu Timur. Jurnal Administrasi Publik Jurusan Ilmu Administrasi Negara Universitas Muhammadiyah Makassar. Volume 2 Nomor 2.

Nurdin, I. \& S. Hartati. (2019). Metodologi Penelitian Sosial.

Efendi, E. (2016). Implementasi sistem pertanian berkelanjutan dalam mendukung produksi pertanian. Jurnal Warta, 43, 1689-1699.

Fallis, A. (2013). Teori Kebijakan Implementasi. Journal of Chemical Information and Modeling, 53(9), 1689-1699.

Gulo, W. (2015). Metodologi Penelitian. 1-27.

Hidayatun, H., Roessali, W., \& Ekowati, T. (2018). Analisis Potensi Pengembangan Komoditas Salak Pondoh (Salaca edulis) di Kapanewon Banjarmangu Kabupaten Banjarnegara. AGRISAINTIFIKA: Jurnal Ilmu-Ilmu Pertanian, 2(1), 60. https://doi.org/10.32585/ags.v2i1.219.

Ikhsan, K.N., \& Hadi, S. (2018). Implementasi dan Pengembangan Kurikulum 2013. In Jurnal Edukasi (Ekonomi, Pendidikan dan Akuntansi) (Vol. 6, Issue 1, p. 193). https://doi.org/10.25157/je.v6i1.1682. 
Prosiding Seminar Nasional Pembangunan dan Pendidikan Vokasi Pertanian

Politeknik Pembangunan Pertanian Manokwari, 31 Juli 2021

e ISSN : 2774-1982

DOI : https://doi.org/10.47687/snppvp.v2i1.173

Kurnia, Undang \& Sutrisno. (2008). Strategi Pengelolaan Lingkungan Pertanian. Jurnal Sumberdaya Lahan Balitbang Kementrian Pertanian Volume 2 Nomor 1.

Manongga, \& Alaman, S.P. (2018). Implementasi Program Keluarga Harapan Dalam Mengatasi Kemiskinan Di Kelurahan Pinokalan Kota Bitung. Implementasi Program Keluarga Harapan Dalam Mengatasi Kemiskinan Di Kelurahan Pinokalan Kota Bitung, 1(1), 1-10.

Mustakim, M. \& Fikriman, F. (2018). Implementasi Pembangunan Pertanian di Era Otonomi Kalurahan (Studi Kasus Dusun Karya Harapan Mukti Kapanewon Pelepat Ilir Kabupaten Bungo). Jurnal Galung Tropika, 7(3), 236. https://doi.org/10.31850/jgt.v7i3.402.

Prihatman, K. (2000). Salak. 2,1-16. http://www.warintek.ristek.go.id/pertanian/salak.pdf

Rivai, R. S. (2011). Konsep Dan Implementasi Pembangunan Pertanian Berkelanjutan Di Indonesia. Forum Penelitian Agro Ekonomi, 29(1), 13-25.

Rosmini, R., Lakani, I., \& Najamudin, N. (2019). Pengembangan Potensi Masyarakat Melalui Penerapan Sistem Pertanian Berkelanjutan Di Kapanewon Bukal Kabupaten Buol Propinsi Sulawesi Tengah. Jurnal Abditani, 2(1), 22-28. https://doi.org/10.31970/abditani.v1i0.16.

Shoffiyati, I. (2019). Analisis Penerapan Standar Operasional Prosedur ( Sop ) Dalam Berusahatani Salak Pondoh Berorientasi Ekspor i Kabupaten Magelang Skripsi Sarjana Pertanian Disusun oleh : Inayah Shoffiyati. Skripsi. Sarjana S1.

Siyoto, S. (2015). Dasar Metodologi Penelitian. Literasi Media Publishing.

Suadya, W.I., A.P. Hadi, \& D.L. Miharja. (2020). Penguatan Kelembagaan Kelompok Tani melalui pelatihan pengelolaan administrasi dalam mendukung pencapaian kegiatan ekonomi di Desa Gumantar Kabupaten Lombok Utara. Jurnal Pepadu Fakultas Pertanian Universitas Mataram. Volume 1 Nomor 3.

Sutono. (2017). Analisis Komunikasi dalam Organisasi. Jurnal Psikologi Islam Al Qalb UIN Imam Bonjol Padang Jillid 9 Edisi 2.

Suskendriyati, H. (2000). Studies on Morphological and Phylogenetic Relationship of Salak Pondoh Varieties (Salacca zalacca (Gaert.) Voss.) at Sleman Highlands. Biodiversitas, Journal of Biological Diversity, 1(2), 59-64. https://doi.org/10.13057/biodiv/d010204.

Yulianto, H. (2016). Menghindari Kekerasan dalam pengelolaan karakter siswa. Jurnal Pembangunan Pendidikan. Pascasarjana Universitas Negeri Yogyakarta

Warasta, D. (2009). Pengembangan Salak Pondoh(Salacca zalacca (Gaert.) Voss.) Ramah Lingkungan di Kalurahan Mardikorejon Kapanewon Tempel Kabupaten Sleman Propinsi. 